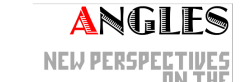

ANELOPHONE WORLD

\section{Angles}

New Perspectives on the Anglophone World

5 | 2017

The Cultures and Politics of Leisure

\title{
Outdoor Leisure Activities in Simon Roberts's We English Photographic Project: Re-writing landscape and nation
}

Karine Chambefort

\section{(2) OpenEdition \\ Journals}

Electronic version

URL: https://journals.openedition.org/angles/1241

DOI: 10.4000/angles. 1241

ISSN: 2274-2042

Publisher

Société des Anglicistes de l'Enseignement Supérieur

\section{Electronic reference}

Karine Chambefort, "Outdoor Leisure Activities in Simon Roberts's We English Photographic Project: Re-writing landscape and nation", Angles [Online], 5 | 2017, Online since 01 November 2017,

connection on 06 June 2022. URL: http://journals.openedition.org/angles/1241 ; DOI: https://doi.org/ 10.4000 /angles. 1241

This text was automatically generated on 6 June 2022.

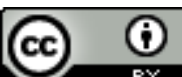

Angles est mise à disposition selon les termes de la Licence Creative Commons Attribution 4.0 International. 


\title{
Outdoor Leisure Activities in Simon Roberts's We English Photographic Project: Re-writing landscape and nation
}

\author{
Karine Chambefort
}

In 2008, Simon Roberts worked with a large-format camera to produce fifty-six views of the English landscape featuring groups of people engaged in outdoor leisure activities. By choosing, in a rather provocative way, to call his book We English (Roberts 2008), the photographer posited the relationship between the leisure activities recorded in his photographs and a sense of national identity or Englishness. The unabashed flagwaving tone of the title is also found on the book cover, quite literally: it shows Saint George's flag and the green silhouette of England on a bluish background, looking like an island on its own, separated from Wales and Scotland, and other British Isles (Figure 1). 


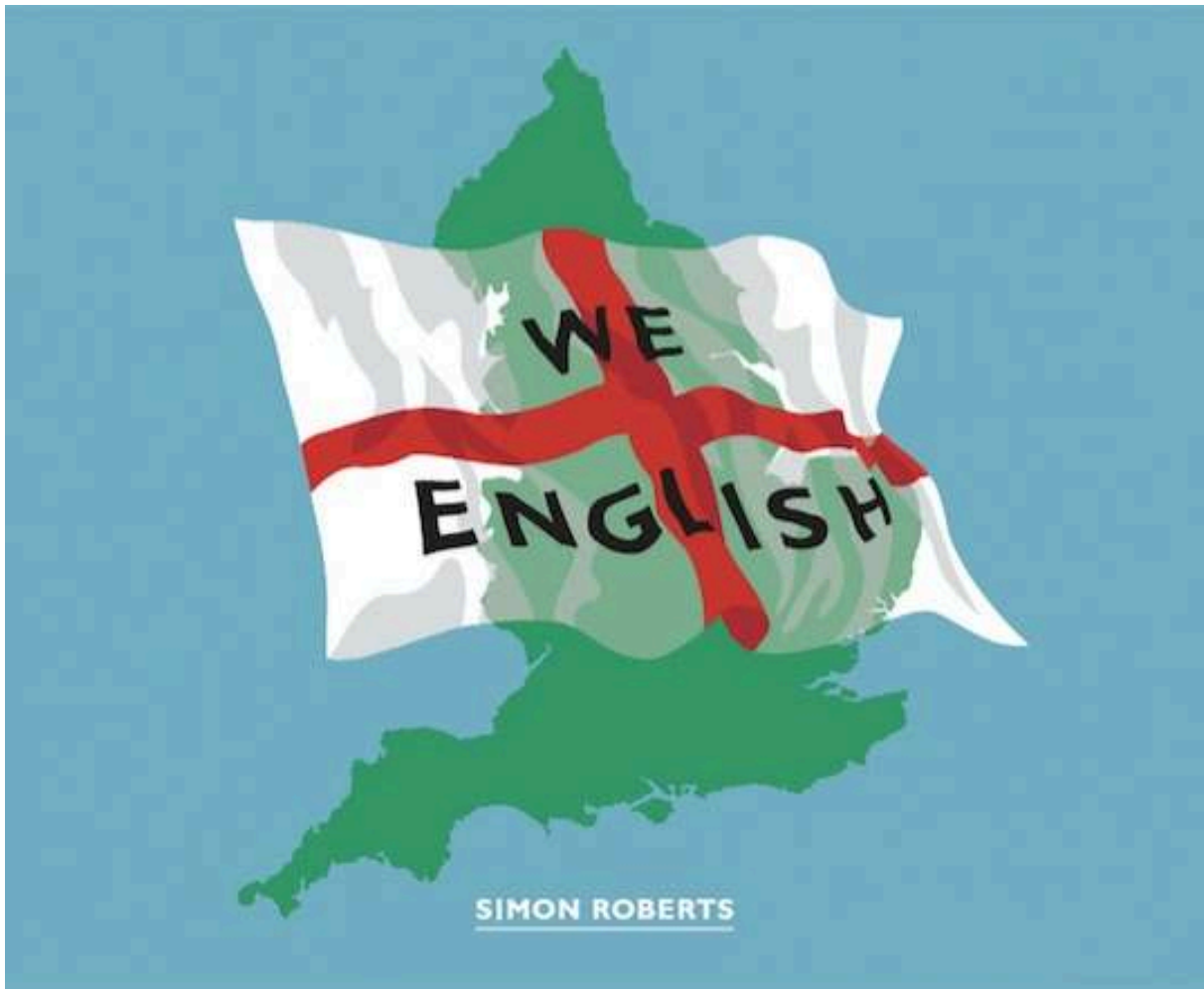

Copyright: Simon Roberts, All Rights Reserved. Source: http://www.simoncroberts.com/wp-content/ uploads/2011/11/Simon_Roberts-We_English_Logo.jpg

This echoes the fairly recent emergence of English nationalism in the British public sphere: since the development of Scottish and Welsh nationalism in the 1990s and the devolution of powers, the question of English identity as distinct from British identity has been raised. Besides, a form of political nationalism is now active in England pushing for English votes on English laws in Westminster. ${ }^{1}$

In that context, the provocative title and eye-catching cover of We English seem to be direct claims that the photographs inside the book - namely, pictures of people spending their free time outdoors - may provide clues to a definition of a distinctive English identity. This implies that the English can be characterized by contrast with the Others, whoever they are, that there is such a thing as typically English leisure, and that it can be evidenced through pictures.

It is not the purpose of this article to discuss - again - the notion of photographic evidence. As a matter of fact, from a strictly sociological point of view, We English fails to represent the $82,9 \%$ of the English population ${ }^{2}$ who live and entertain themselves in urban areas most of the year, and those who prefer indoor leisure activities. The question here is not so much about the sociological truthfulness of We English. Nor is it about the documentary quality of Simon Roberts's pictures. It is true that the fifty-six pictures in the book are documentary in style, with a distant-observer perspective, usually from a slightly elevated position. However, let us stress that, like any photographs, they result from multiple processes of selection, at various stages of the project: from the initial choice of places and subjects to the final editing processes for the book and exhibitions, out of hundreds of plates produced across England during a year-long road trip. As photographer Paul Graham once put it, taking photographs, 
including documentary photographs, involves "selecting elements from the world and putting them together to make up another world." ${ }^{3}$ Consequently, this paper will not dwell on the documentary quality of the photographs of We English, but mostly on their narrative quality. Our main concern here is the selection and choices operated by the photographer: what kind of England is put together by those photographs of outdoor leisure and to what extent does it break from previous narratives? In other words, we will be looking at the ways a representation of outdoor leisure in England serves a narrative on English identity and perhaps on nationalism in general.

And the least we can say, as a last word of introduction, is that We English has been a powerful narrative, with quite an exceptional career in contemporary British visual culture. The list of venues where the series has been exhibited, plus the number of newspapers in which it has been reviewed, reveal unprecedented levels of circulation. Just to name a few places, We English was shown at the Photographers' Gallery, London (2009), the National Media Museum, Bradford (2010), the mac, Birmingham (2011), the Brighton Museum and Art Gallery (2011), Flowers East gallery, London (2011), and Third Floor Gallery, Cardiff (2012), in other words, in most of the art and photography venues that count in the UK. Few, if any, series in the history of British photography, have known such publicity and success. ${ }^{4}$ Therefore, anyone interested not just in photography, but in British culture and politics should engage with this narrative.

\section{Outdoor leisure as cultural theatre?}

6 It is important to deal with a photobook as a whole and as an object in itself, as Martin Parr has reminded us in his history of the photobook (Parr and Badger). Simon Roberts obviously took special care in editing his book for publication so as to cover a vast range of leisure activities in We English. About twenty different leisure practices are represented, with a few of them recurring several times, like seaside promenading, hiking, picnicking, bathing and sunbathing. Yet we may wonder how truly English all these activities are. Pastimes like promenading on beaches or picnicking in parks are rather common or even universal. As a matter of fact, most of the outdoor activities represented in We English are not much different from those of other people in other nations. For instance, similar photographs of outdoor leisure were produced in Russia by Simon Roberts himself in his previous project Motherland (2007) or by Russian photographer Alexander Gronsky. ${ }^{5}$ There is also much resemblance with some of Massimo Vitali's images of Italian beaches. Such similarities may point to a standardization of pastimes and behaviours in the wake of globalization. They also seem to indicate that only the choice of location by the photographer, that is to say, the landscape - rather than the activities themselves - lends the scenes their supposedly distinct and specifically national character.

7 A number of features traditionally associated with rural England are recognizable in the book. Almost a quarter of the pictures are seaside pictures - like Woolacombe Bay, Devon or Holkham, Norfolk - which repeatedly remind the viewer of the insular nature of the country and echoes the graphics on the book cover designed by FUEL. Similarly, a few views of the enclosed fields typical of the English countryside are instrumental in identifying the landscape as truly English (see the pictures of Stanage Edge, Hathersage, Derbyshire and of Fountains Fell, Yorkshire Dales). Such identification stems from a whole terrain of previous representations in visual culture, from 
landscape painters Richard Wilson and John Constable to photographer Fay Godwin (Godwin 1990). These references are acknowledged by Simon Roberts, for instance when he deems his picture of the Haxey Hood to be "Constable-esque, with the Church spire, flat horizon and rolling skies." (Roberts 'commentary') (Figure 2)

Figure 2: Simon Roberts, 'Haxey Hood'

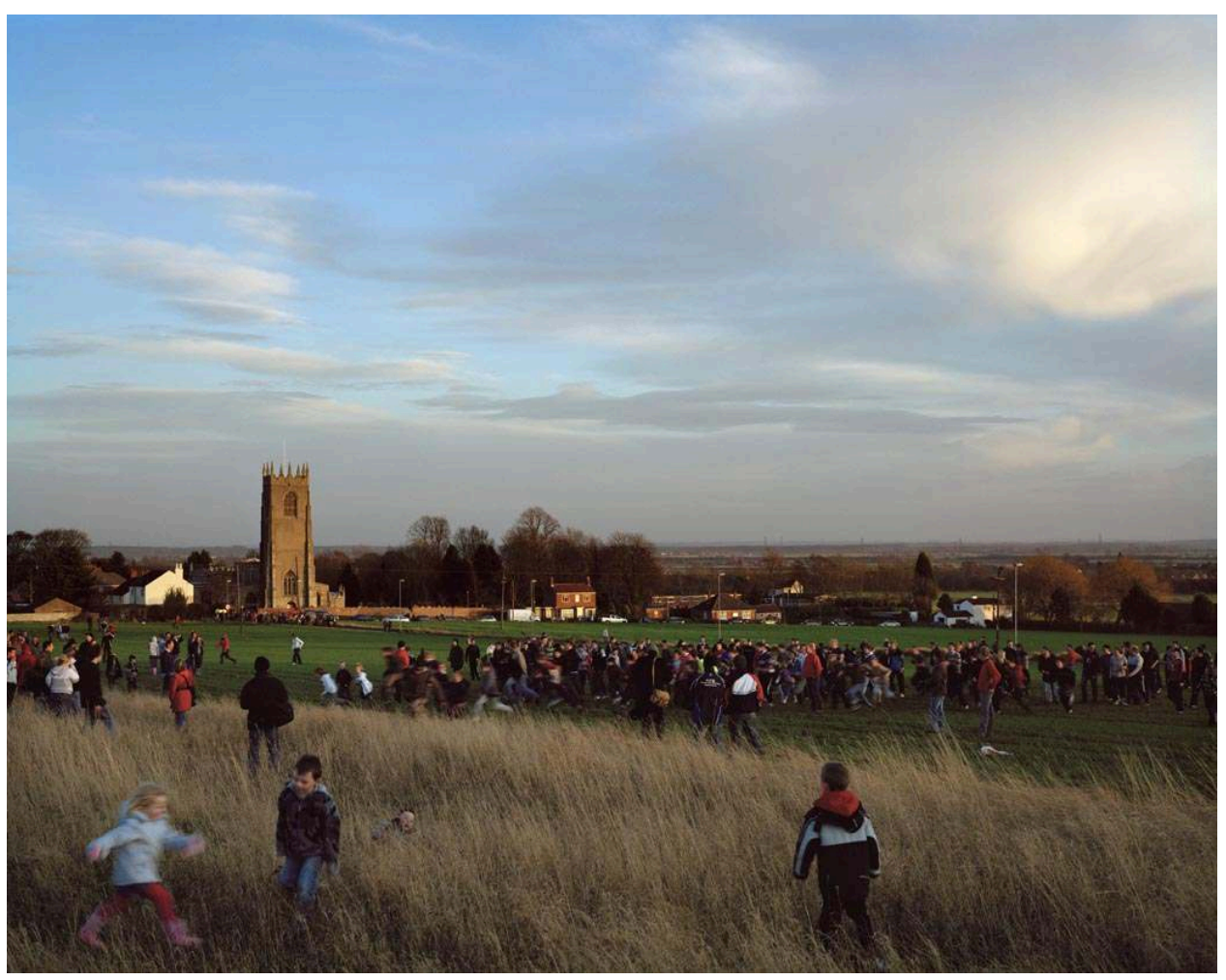

Copyright: Simon Roberts, All Rights Reserved. Source: http://www.simoncroberts.com/wp-content/ uploads/2011/09/Simon_Roberts-We_English-08.jpg

8 As shown by John Taylor in A Dream of England, past representations of the English landscape shape the imagination of contemporary tourists and viewers. They frame their idea of landscape and leisure, which in turn informs their definition of the national community. A process of repetition is at work, which Taylor identified as one of the chief characteristics of tourist imagery: it "reliably re-presents the already known. It guarantees a high level of a group solidarity and satisfaction." (Taylor 243) Although the pictures in We English are not postcard pictures, they sometimes hint at touristic imagery and seem to question it. This was particularly emphasized when some pictures from We English were actually published as postcards to promote the Bradford exhibition. Thus an open dialogue is engaged with representations of landscape from both the history of art and tourist imagery, so that the Englishness of landscape, rather than the Englishness of pastimes, takes centre stage.

9 A few exceptions to this can be found with photographs of some outdoor activities that have been constructed in collective memory as typically English through recurring representations in visual culture. Simon Roberts explicitly addresses this legacy. As he explained in a 2012 interview, ${ }^{6}$ not only was he inspired by the works of Flemish painter Lucas Van Valckenborch, who painted bird's eye views of village life near Antwerp (1575) in the late 16th century; but he also founded his project on a whole set 
of references from British visual culture. Indeed, interest in leisure activities in British art can be traced back to 18th century conversation pieces, some of which were set outdoors, depicting garden parties, or members of the aristocracy going for strolls and hunts on their estates (Shawe-Taylor 2009). Simon Roberts's picture of hunters shooting birds at Heberdens Farm (Finchdean, Hampshire) reminds the viewers of this long tradition, even though there is no indication of the social status of the people there. In the 19th century, sporting events became popular and provided painters with opportunities to produce almost ethnographic representations of the social stratification of English rural life: cricket matches and horseraces were featured in paintings like William Powell's Derby Day (1856-8) or John Roberston Reid's Country Cricket Match (1878). Over the years and with the help of photography, these activities have come up so often in pictures of England that they have become motives, and eventually, national icons. After Frith, Derby Day, at Epsom, was pictured by CartierBresson (1955), Homer Sykes (1970), Josef Koudelka (1972) or Martin Parr (2004), just to name a few. Simon Roberts acknowledges this lineage by literally referencing previous representations: "this is my reinterpretation of Frith's painting," (Roberts 'Commentary') he comments about his photograph of Derby Day at Epsom at the end of his book (Figure 3).

Figure 3: Simon Roberts, 'Derby Day at Epsom'

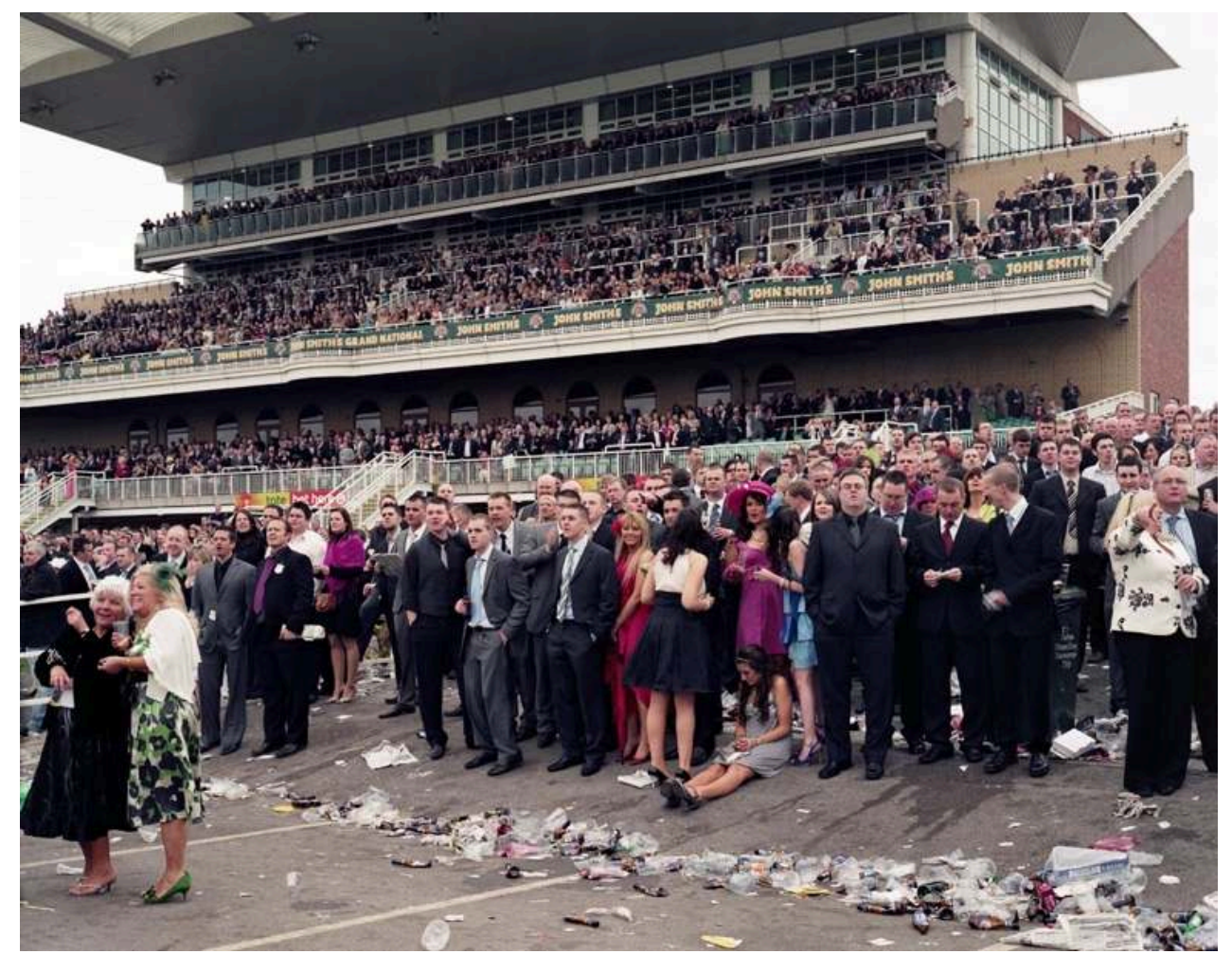

Copyright: Simon Roberts, All Rights Reserved. Source: https://www.simoncroberts.com/wp-content/ uploads/2011/09/Simon_Roberts-We_English-15.jpg

10 As for more typically working-class pursuits, they have been seldom represented in painting in past centuries, not that the working class had no leisure time at all, as Emma Griffin (2005) has shown. There are a few representations of fairs like that of Croydon by George Hawkins (1833) or much later, the Lancashire Fair by L.S. Lowry (1946). Simon Roberts's photograph of the Epsom fun fair in We English definitely 
echoes those previous representations. In terms of popular outdoor activities, beachgoing and bathing have been more prominent in visual culture. Pictures of seaside resorts have long been icons reflecting the development of popular holidays. As early as 1827 , Constable had produced one of the first representations of modern seaside leisure in Chain Pier, Brighton (1827): he was recording the ongoing transformations of landscape with the building of the Pier in the background, the Marine Parade in the middle ground and the presence of bathing huts on the beach where ladies and children are walking or bathing, mixing with fishermen at work in the foreground. In the 1980s, Blackpool beach-goers were photographed by Chris Steel-Perkins (2009), while New Brighton's working class holiday-makers gave Martin Parr the subject for what was to be his breakthrough series The Last Resort (Parr 1986). Simon Roberts, who belongs to the next generation of British photographers, suggests that his own pictures of Blackpool promenade and beach could be seen as a sequel to this.

11 The photographer even encouraged comparisons by including a timeline of British photographers on the blog he dedicated to We English. He considers his own contribution as an "update" on previous records. According to him, this is a timely update, as there has been new popular interest in English locations for outdoor leisure and tourism since the 2008 credit crunch. The media even coined the phrase "staycation" to describe this "rediscovery" of England, as many people could no longer afford to travel abroad for their holidays.

Therefore, the supposed Englishness of some of the pastimes pictured in We English results both from centuries-old practice and from recurring representations. It implies continuity and memory, as some pursuits have been transmitted, reproduced, and represented. Indeed, visual culture is one way the "imagined community" takes shape. Benedict Anderson, who coined the phrase, showed that national identities and traditions are not only invented, as Hobsbawn insisted (Hobsbawm and Ranger), but also interiorised by people through various means. They are constantly re-activated by the work of educational institutions, the media, or museums, as French historians Anne-Marie Thiesse and Philippe Noiriel have also shown. So we may consider that We English is a photographer's contribution to this ongoing "imagining" process and we have seen that Simon Roberts does claim to play his part in this chain writing of national icons.

\section{A dialogical approach}

Besides digging into English visual culture, Simon Roberts also turned to the public to suggest typically English pastimes and places for his project. People were asked to send in ideas through the photographer's blog and forum. As he was travelling around the country in a motorhome, he posted news of his whereabouts in The Times and in the local press so that people could direct his attention to specific locations and events. The archive for this public consultation is still available today online ${ }^{7}$ and offers an interesting insight into what people consider typically English leisure. Most of the time, they mention cultural heritage and previous representations. Sometimes, they tend to rehash what seems to be stereotypes on English eccentricity. Nonetheless, it is worth noting that, while taking up some national icons, Simon Roberts managed to steer clear of clichés on the English character, notably the supposed taste for strange pastimes. Only one photo shows a rather funny activity: Mad Maldon Mud race where joggers 
have to cross the Blackwater Estuary at low tide and trudge in mud (Figure 4). In his comments on the book, Simon Roberts is prompt to stress that "We English is resolutely not a catalogue of quirky pastimes undertaken by eccentrics." About Mad Maldon Mud race, he insists that the race was invented in 1973 and has not been a long tradition as the story has it.

Figure 4: Simon Roberts, 'Mad Maldon Mud race'

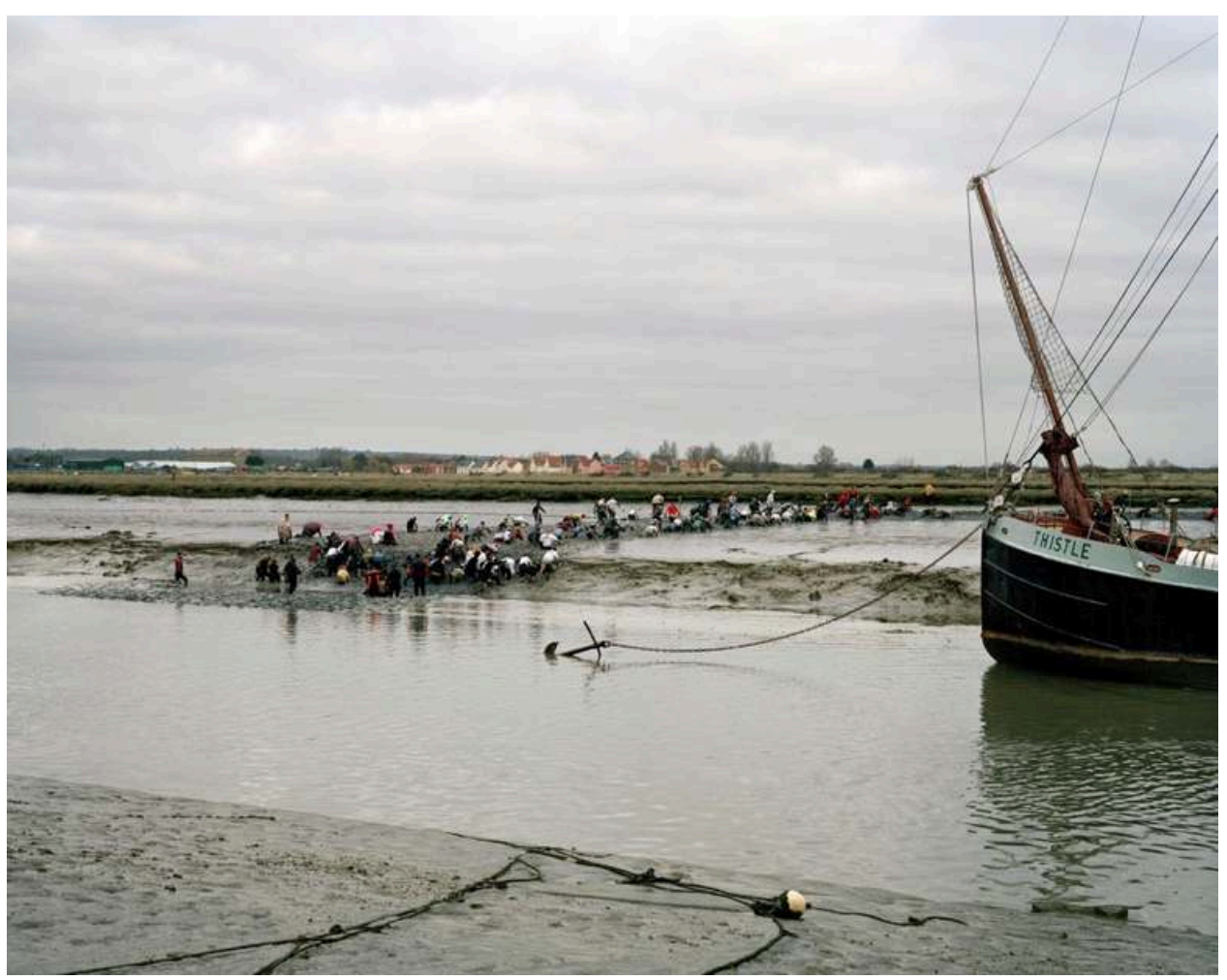

Copyright: Simon Roberts, All Rights Reserved. Source: https://www.simoncroberts.com/wp-content/ uploads/2011/09/Simon_Roberts-We_English-07.jpg

Interestingly, the public consultation for We English also reveals that some members of the public preferred to go down memory lane, suggesting very personal activities or locations. And so did Simon Roberts, when he decided to photograph the place where he used to go tobogganing as a child or the beach near his grand-parents' home. In that case, English leisure activities would simply be the mundane practices of English people in their familiar environment. From that angle, the nation is conjured up as a network of personal memories from the many individuals who have been living, or in some cases, used to live in England. This suggests that people develop roots and a sense of belonging through leisure activities that are not specifically English but are related to English places in their personal memories.

In a nutshell, the activities and places represented in We English were selected along different but complementary lines. The photographs result from negotiations between personal and collective memories and from negotiations between inherited cultural representations and ongoing relationships to leisure and landscape. Simon Roberts made this clear by establishing an online dialogue with the public ahead of the project and by explaining his choices in retrospect in the book's comments pages. Overall, he developed a reflexive approach that is perhaps lost to the viewers who discover the 
photos in galleries without a full view of the project. Yet, what comes out of such a dialogical creation is a more open definition of Englishness and national identity than traditional views based on ethnic identity and so-called cultural values. Here, outdoor leisure activities and landscape are not deemed to be a mere cultural theatre.

\section{Outdoor leisure as social theatre}

In We English, leisure activities are also represented as the terrain for many social interactions, or as a social theatre, mainly through a number of aesthetic devices.

First of all, let us stress that all the places represented in We English are public places with a majority of beaches and parks, which means, on the whole, rather vast tracts of land. No one is seen barbecuing in their own backyard, although it surely is a favourite, weather permitting. When gardens are shown, they are allotments in Middlesbrough, that is to say, gardens run collectively, which are known to allow for shared moments. Second, the photographer decided to look mainly at groups of people. Only two pictures out of fifty-six feature just one person or two. Third, photos are always shot from a distance so that people are often figures dotting the landscape, clustering here and there. They can rarely be recognized individually. These photographic choices called for the use of a specific camera which could at once frame vast areas of landscape and still record and retain a richness of detail on print. Simon Roberts opted for a large format camera, involving the use of a single plate for each shot, a rather long exposure time, which requires a tripod, a dark cloth and a shutter release cable. In that position, the photographer is a distant observer and has little interaction with the subjects in his pictures who tend to forget about his immobile presence and to be unaware of the 'decisive moment' when he releases the shutter. This ads to the impression of a theatre as the photographer himself stands as a spectator rather than a participant in the scene. All the subjects are indeed busy with their various activities, interacting with each other.

Furthermore, Simon Roberts used an elevated perspective (often taking pictures from the roof of his motorhome) so that the picture plane tends to open and the middle ground is made more visible. This aesthetic choice is a departure from the conventional perspective used in pastoral representations of England. It creates a new sense of openness by contrast with the intricacy usually found in picturesque paintings like those of Constable. The human figures are revealed to be truly scattered in space. Photographs of beaches like those of Blackpool show how evenly people are distributed, keeping a respectful distance from others and making the most of the available space. A form of continuity is created between the foreground and the middle ground, which emphasizes interactions between subjects in different areas of the picture and an engagement with space rather than a relationship between the photographer and the people in the foreground.

Because of all the aesthetic choices we have just described, outdoor leisure activities in We English take a social dimension. The many individual connections with landscape during leisure activities in public places produce a form of connection between people. Landscape is not merely the backdrop for those activities: it is shared space, where convivial moments are spent. So there is a sense of community through shared environment, more than community through shared culture. We are looking at a kind of social theatre beyond the cultural theatre. This means that the photographer's 
aesthetic choices tend to transcend and overwhelm the thematic choices that we have analysed in our first part. I would suggest that Simon Roberts tends to shift ground through formal devices to consider nationality in terms of participation, or perhaps citizenship, beyond history and culture.

From that angle, the pictures of We English are more political than they seem. They offer a re-definition of identity formation and national belonging. We saw on the one hand that Englishness can be found in personal and collective memories, in cultural references from the past which are re-produced and appropriated through visual culture. On the other hand, it seems that the aesthetic codes of the photographs in We English prove national belonging to be also written in the present. It is the paradoxical nature of photography to both capture the present and produce a record. Here, photographs seize the ongoing dynamics of collective identity formation. They imply that the English are all the people who happen to be here at this moment whatever their ethnic identity or cultural background. In fact, there is a good chance that some people in Simon Roberts's pictures would not identify as English on a census form. In our view, this is very well epitomized by the picture of Derwentwater lake (Kenswick, Cumbria) where families are strolling on a sunny day: in the middle of the picture, two groups have met and stopped for a chat. The two families are visibly different, as the one on the left can be identified by their clothes as a Muslim family. Nonetheless, what is happening here in the social theatre of a Sunday stroll around the lake, is not ethnic distinction and division. On the contrary, the visual language of the photograph produces a very inclusive narrative.

21 This stands in contrast with the brashly nationalistic and exclusive title and cover of We English. "We English" suggests that there are such things as essential characteristics, an innate form of Englishness, which makes the English different from others. There is definitely a "them-and-us" ring to this title which implies that group identification arises from a sense of difference from other groups. Yet, ironically, as the viewer goes over the pictures, the assertiveness of the title dissolves into a much more complex view. This discrepancy urges the viewers to think again of England, and more generally, of the nation.

\section{New perspectives on rural England?}

The visible sense of openness and conviviality in We English definitely contrasts with notions of a parochial, stratified, ethnocentric rural England previously raised by some critics about pastoral representations of the nation in visual culture, in the heritage industry and in tourist imagery (for eg. Short 1992; Helsinger 1997; Hewison 1987). From that prospect, it may be said that Simon Roberts offers a re-writing of rural landscape.

In most pictures, the prevailing impression is that anyone can access most of the places and outdoor pursuits represented. Many leisure activities are virtually free and available for all. A few pictures still hint at class divide, like that of Cirencester Park Polo Club. However, as Simon Roberts commented on his photograph of a shooting party in Heberdens Farm (Finchdean, Hampshire), things are not always what they seem: the hunters in the picture are not upper-class landowners, but a group of builders that he describes as "aspiring", pointing to a certain social mobility in rural England. 
On a similar note, limited ethnic diversity has also been one of the features of rural England. In the 80s, photographers like Ingrid Pollard showed that the English countryside and its visual representations had excluded ethnic minorities. Pollard's series Pastoral Interlude pointed that the presence of black people in rural England still felt odd in 1987 (Pollard 1987). The text that she associated to her image of a black lady posing with her back to a wire fence and a view of England's "green and pleasant land" bitterly echoed Wordsworth's idyll:

[...] it's as if the Black experience is only lived within an urban environment. I thought I liked the Lake District where I wandered lonely as a Black face in a sea of white. A visit to the countryside is always accompanied by a feeling of unease, dread [...] (Pollard 1987)

In We English, it seems that this has been put to rest. Black and ethnic minority people (to use the British sociological terms) are indeed present in many pictures, but no particular emphasis is placed on that detail. They are just part of the crowd, as in the picture of Keynes Country Park Beach (Shornecote, Gloucestershire). In the photo of Lindisfarne Castle, a black lady is going through a gate on her way out of the castle site. This part of the picture may seem to some viewers as an update to Pollard's famous shot; but it is worth noticing that here, the lady features among many other people, perhaps forming a couple with the white man also going through the gate, which points to social transformations in England in the past thirty years. Simon Roberts makes similar comments about another picture in the series:

This photograph was taken at Stanage Edge in the Peak District, a popular destination for rock climbers. In the mid-ground a Muslim couple wearing distinctive grey robes follow a footpath down the hillside. We tend to think of these kinds of views of rural England being inhabited by the white middle classes, and I like that this photograph challenges the stereotype. Talking to the couple depicted, I learned that they were from Leicester on a week's walking holiday, staying at a $B \& B$ in the nearby village of Hathersage. They spoke of feeling completely at ease in the area and described how they often spend their holidays exploring the English countryside. (Roberts 'Commentary')

Contrary to Pollard's feeling of "unease" back in the 1980s, this Muslim couple say they are "completely at ease" in the English countryside. Thus the outdoor leisure activities represented in We English are shown to be occasions when people simply live their lives and engage with the environment they share with the rest of the population without much questioning it.

Finally, the vast range of activities compiled in the series reveals the influence of other countries on England. It tends to indicate the changing nature of both rural life and tourism, contrary to what heritage does. For instance, the development of camping and caravanning in parks, as in Gordale Scar Campsite (Malham, North Yorkshire), has probably been inspired more by American outdoor culture than by English tradition. The same goes for surfing, pictured in Salcombe Sands (Devon). Leisure activities and access to the countryside and seaside have evolved, so that rural England seems to have been become more outward-looking on many accounts.

However, this view should be qualified, by remarking on the great degree of control that has accompanied this transformation of leisure and rural England, which is particularly visible in Simon Roberts's pictures.

It has always been a feature of the representation of English landscape to stress the domestication of nature over the wilderness. Picturesque paintings of English 
landscape made little room for untamed nature. Painters looking for sublime views of uncultivated ragged mountains were more likely to turn to Wales, like Richard Wilson for his view of Llyn y Cau (1774), or to Scotland. English landscape, by contrast, was mostly mapped, enclosed and organized territory. Even as tourism developed in Britain in the 19th century, new connections with nature were made, but they mostly consisted in visiting selected beauty spots. One picture by Simon Roberts epitomizes this harnessing of nature: in the landscaped gardens of the Northington Grange, a very smartly dressed couple are having a picnic during the Opera festival; a black fence cuts the green scenery into two strictly delineated areas. What lies beyond the fence, though, is also cultivated land, for agricultural purposes.

Besides this organization of landscape, Simon Roberts's photos often subliminally point to a parallel regulation of outdoor leisure activities. In many pictures, everything seems to be organized for safe and comfortable leisure. Even Scafell Pike summit bears the marks of human presence with a piece of a drystone wall: the hikers, all perfectly equipped to face hostile natural elements, are checking maps, watches or perhaps compasses, implicitly reminding us that everything but the weather in under control. The fences and hedges typical of enclosed land that are visible in many pictures are complete with gates, walking paths, and signs. In the picture of Dunstanburgh Castle, the concern for safety is emphasized by the yellow jackets that cyclists are wearing. In other pictures like that of Delamere Forest Park, picnicking takes place on picnic tables in designated areas. In a few instances, designated areas end up being crowded as in Keynes Country Park Beach (Gloucestershire). The organization of space and leisure reaches a climax in the picture of Burrs Country Park Caravan Club near Manchester where the road and grass pitches form an abstract geometric pattern.

31 Many pictures suggest that outdoor leisure activities are valued and encouraged as long as they remain on the provided tracks. They evidence an increasing regulation and standardization of leisure practices in England, which perhaps qualifies the openness and dynamism that we have described previously. Such "consistent concern for order and control" (Matless 153) has been analysed by David Matless as the "moral geographies of English landscape" and leisure in the 1930s and 40s. Yet, judging by most pictures in We English, it is arguably still true that "we have an ecology of pleasures whereby people and their practices are mapped in a necessary relationship with particular environments, and -in the case of those not recognizably part of an open-air culture- are not to take themselves or their practices into other environments." Thus, Simon Roberts's project opens onto complex "dialectics of freedom and power, popular pleasure and citizenship" (Matless 154) and suggest that defining England through outdoor leisure and landscape is not just a matter of cultural geography but also of moral and political geography.

\section{Conclusion}

Besides choosing outdoor pursuits and places to be photographed for his series We English, Simon Roberts made aesthetic choices which shape a discourse on leisure and nation that lies beyond cultural types and locations. The photographer debunks the idea of outdoor leisure as a mere cultural theatre. He proposes a more personal and complex view, suggesting that national identity cannot be defined merely in terms of heritage, cultural values and practices. Outdoor leisure is also a social theatre. 
Openness and conviviality prevail in most pictures so that We English offers a rather refreshing view of rural England, and more generally, of a nation which contemporary politics have shown to be tempted by retreat and backlash. Here, on the contrary, Englishness and, more generally, nationality are examined in terms of participation, of political and moral geography. This certainly accounts for the very broad appeal of Simon Roberts's project and its success beyond the borders of England.

\section{BIBLIOGRAPHY}

Anderson, Benedict. Imagined Communities: Reflections on the Origin and Spread of Nationalism.

London, Verso, 1983.

Daniels, Stephen. Fields of Vision: Landscape Imagery and National Identity in England and the United States. Princeton, NJ: Princeton UP, 1993.

Gilroy, Paul. After Empire: Multiculture or Postcolonial Melancholia. London: Routledge, 2004.

Godwin, Fay. Our Forbidden Land. London: Jonathan Cape Ltd, 1990.

Griffin, Emma. England's Revelry: A History of Popular Sports and Pastimes, 1660-1830. Oxford: Oxford UP/ British Academy, 2005.

Helsinger, Elizabeth K. Rural Scenes and National Representation: Britain, 1815-1850. Princeton, NJ: Princeton UP, 1997.

Hewison, Robert. The Heritage Industry: Britain in a climate of decline. London: Methuen, 1987.

Hobsbawm, Eric and Ranger, Terence (eds.). The Invention of Tradition. Cambridge: Cambridge UP, 1983.

Kumar, Krishan. The Making of English National Identity. Cambridge, New York: Cambridge UP, 2003.

Lodge, Guy. The Dog that Finally Barked: England as an Emerging Political Community. Institute for Public Policy Research, 2012.

Matless, David. “Moral geographies of English landscape”. Landscape Research 22(2) 1997: 141-155. $10.1080 / 01426399708706505$

Morley, David and Robins, Kevin (eds.). British Cultural Studies: Geography, Nationality, and Identity. Oxford: Oxford UP, 2001.

Noiriel, Gérard. À quoi sert «l'identité nationale »? Marseille: Éditions Agone, coll. 'Passé \& présent', 2007.

Noiriel, Gérard. Qu'est-ce qu'une nation ? Paris: Bayard, 2015.

Parr, Martin. The Last Resort. Manchester: Dewi Lewis Publishing, 1986.

Parr, Martin and Bagder, Gerry. The Photobook: A history. volume 1, London: Phaidon, 2004.

Roberts, Simon and Daniels, Stephen. We English. London: Chris Boot, 2009. Includes:

"Commentary" section, unpaged. 
Shawe-Taylor, Desmond. The Conversation Piece: Scenes of Fashionable Life. London: Royal Collection Publications, 2009.

Short, Brian. The English Rural Community: Image and Analysis. Cambridge: Cambridge UP, 1992.

Skey, Michael. National Belonging and Everyday Life: The Significance of Nationhood in an Uncertain World. Basingstoke, Palgrave Macmillan, 2011.

Steele-Perkins, Chris. England. My England. Newcastle: Northumbria Press, 2009.

Taylor, John. A Dream of England: Landscape, Photography and the Tourist's Imagination. Manchester: Manchester UP, 1994.

Thiesse, Anne Marie. La création des identités nationales. Paris: Éditions du Seuil, 1999.

Urry, john. The Tourist Gaze. London: Sage Publications, coll. “Theory, Culture \& Society”, vol. 1., 2002.

Wells, liz. Land Matters: Landscape Photography, Culture and Identity. London: I.B. Tauris \& Co., 2011.

\section{Website}

Roberts, Simon, We English, [Blog], http://we-english.co.uk

\section{Pictures/Paintings/Photographs}

Hawkins, George. Croydon Fair. 1833, (watercolour and ink on paper), Croydon Art collection, Croydon Clocktower.

Lowry, L.S. Good Friday, Daisy Nook. 1946, The UK Government Art Collection. https:// artcollection.culture.gov.uk/artwork/296/

Pollard, Ingrid. Pastoral Interlude. 1987, (Gelatin silver print coloured by hand, 25.5x38.8 cm), Victoria and Albert Museum, London. http://collections.vam.ac.uk/item/0107865/pastoralinterludeits-as-if-the-photograph-pollard-ingrid/

Van Valckenborch, Lucas. Winter landscape near Antwerp with snowfall. 1575, (oak, $61 \times 82.5 \mathrm{~cm}$ ), Städel Museum, Franckfort. http://www.staedelmuseum.de/en/collection/winter-landscapesnowfall-near-antwerp-1575

Wilson, Richard. Llyn y Cau, Cader Idris. Wales, 1774, (Oil paint on canvas, 511 x $730 \mathrm{~mm}$ ), Tate Gallery, London. http://www.tate.org.uk/art/artworks/wilson-llyn-y-cau-cader-idris-n05596

\section{NOTES}

1. English Votes for English Laws: An Explanatory Guide to Proposals, Cabinet Office, July 2015, https://www.gov.uk/government/uploads/system/uploads/attachment_data/file/441848/ English_votes_for_English_laws_explanatory_guide.pdf

2. Office for National Statistics - Rural population and migration 2013/2014, Department for Environment, Food and Rural Affairs, 9 July 2015, https://www.gov.uk/government/statistics/ rural-population-and-migration.

3. Paul Graham, interview with Thomas Weski, at Le BAL, Paris, 15 September 2012, personal notes. 
4. In comparison, Martin Parr's best known series about Britons The Last Resort (1986) and The Cost of Living (1989) or his more international series like Common Sense (1995) and Small World (1999) which have travelled the world extensively, never toured the UK in such an exhaustive manner (for various reasons, not developed here, but mostly due to the very different institutional context for photography in Britain some twenty years ago). See http:// www.martinparr.com/cv/exhibitions/

5. Alexander Gronsky, Pastoral 2, 2008-12 and Massimo Vitali, Rosignano Fins \#5, 2002-06.

6. Interview with the author, Hove, July 2012.

7. Still available here: http://www.we-english.co.uk/your_ideas.php

\section{ABSTRACTS}

Simon Roberts's We English series of photographs produced in 2008 has encountered unprecedented success in Britain and abroad. Recording scenes of outdoor leisure activities in various places in England, it has become in a few years the most exhibited series in the history of British photography. It was also published by Chris Boot as a book of fifty-six photographs. The photos show groups of people involved in a variety of activities like hiking, paragliding, angling, hunting, bird watching, horseracing, tobogganing, "mud-racing", picnicking, or just strolling and relaxing. As the title of the series invites the viewer to consider the Englishness of the activities represented, We English is first analysed as an update on previous representations of English customs, by looking at the rich intertext in Simon Roberts's pictures, through centuries of English visual culture from 18th century paintings to contemporary photography. Yet this article aims to establish that there is more to Simon Roberts's project than merely a cultural theatre where English traditions are re-enacted. It is shown that the photographer has considerably broadened the scope through key aesthetic choices. By exploring the relationship between people and public places, We English turns outdoor leisure and landscape into a social theatre. The sense of community and belonging emerges out of shared environment and space rather than from cultural practices that are reproduced and re-presented over time. This paper argues that this approach allows the photographer to reformulate the question of Englishness and national identity altogether and to offer new perspectives on rural England, with outdoor leisure activities creating a sense of openness and conviviality contrasting with previous notions of a closed, stratified, ethnocentric society.

La série de photographies de Simon Roberts intitulée We English (2008) connaît un succès sans précédent en Grande-Bretagne et dans le monde, sous la forme à la fois d'expositions et d'un livre de cinquante-six photographies. Ces images réalisées avec un appareil à chambre grand format représentent des scènes d'extérieurs dans différents lieux d'Angleterre, où des groupes de personnes s'adonnent à tous genres d'activités de loisirs comme la randonnée, le piquenique, la chasse, le parapente, la promenade ou le farniente à la plage. Le titre We English semble inviter les spectateurs à déceler des caractéristiques typiquement anglaises dans les pratiques et les paysages représentés. Cet article interroge donc en premier lieu la notion d'anglicité à travers les loisirs et les paysages photographiés par Simon Roberts. Ceux-ci constituent-ils un simple théâtre culturel où se jouent et se re-jouent les traditions anglaises ? Les images de Simon Roberts présentent certes un très riche intertexte avec toute la culture visuelle anglaise que nous retraçons brièvement de la peinture à la photographie contemporaine. Elles peuvent en cela être 
considérées comme une contribution de plus à la longue histoire de la représentation des loisirs anglais. Néanmoins, cet article montre comment les choix esthétiques de Simon Roberts tendent à transformer ce théâtre culturel en théâtre social. En effet, au fil des photographies, le sentiment d'appartenance et de communauté semble émerger avant tout du partage de l'espace public et de l'expérience collective, et d'une forme de convivialité. L'anglicité ainsi définie s'avère donc beaucoup plus ouverte et moins ethnocentrique qu'il n'y paraît. Au-delà, la série livre une véritable réflexion sur la notion même d'identité nationale.

\section{INDEX}

Mots-clés: anglicité, loisirs d'extérieurs, paysage, photographie, Grande-Bretagne, Roberts Simon, représentation

Keywords: photography, Great-Britain, Englishness, landscape, outdoors, leisure, Roberts Simon, representation 